'Ervaringen van een jonge bestuursambtenaar in de Molukken' in S.L. van der Wal ed. Besturen overzee (Eraneker, 1977) 73 - 109.

3. W.Ph. Coolhaas 'Kroniek van het Rijk Batjan' Tijdschrift voor Indische Taal- Land- en Volkenkunde (1923) $474-512$

4. H.G. Schulte Nordholt, Het politieke systeem van de Atoni van Timor diss. Vrije Universiteit 1966, 1 - 5.

5. W. Ph. Coolhaas, Het regeeringsreglement van 1827, het werk van 1818 aan de ervaring getoetst. Diss. Utrecht 1936.

6.. W.Ph. Coolhaas, 'Van Koloniale Geschiedenis en geschiedenis van Indonesië; van historici en taalambtenaren'. Bijdragen van het Koninklijk Instituut voor Taal-, Land- en Volkenkunde 1951, 135 - 160. See also John R.W. Smail 'On the possibility of an autonomous history of Modern South East Asia', Journal of Southeast Asian History 1961, 72 - 102.

7. W.Ph. Coolhaas, Verloren Kansen, (Groningen 1955).

8. W.Ph. Coolhas, 'Aanteekeningen en opmerkingen over den zoogenaamden Ambonschen moord' BKI 1942, 49.- 93; -, 'Baud on Raffles' Journal Malaysian_Branch Royal Asiatic Society 1951, 109 - 120.

9. Generale Missiven van Gouverneurs Generaal en Raden aan Heren XVII der Vererigde Oostindische Compagnie 7 vols. ('s Gravenhage 19vi - 1979).

10. James J. Fox, Harvest of the Palm, Ecological Change in Eastern Indonesia (Cambridge Mass. 1977).

\title{
A LETTER FROM CANADA
}

Dear Editors,

19 april 1982

I have delayed replying to your letter of March 8 th until plans for the 1983 conference of the Consortium for 
the Comparative Study of European Expansion (CCSEE) became more concrete. I now have sufficient information to issue a "call for papers". Needless to say, we would be very grateful if you could insert a notice like the following in the June 1982 number of Itinerario.

The first annual conference of CCSEE will take place during mid-May 1983 at Carleton University, Ottawa, Canada. (Precise dates will be settled during the summer.) The conference theme will be "Centering on the Periphery: Historical Stages in the Integration of Third World Societies into the European World Economy". That's quite a mouthful, but basically it comes down to a consideration and a critique of the work of the world systems theorists, principally Immanuel Wallerstein. All scholars interested in the world systems paradigm are invited to participate. We are particularly interested in hearing from colleagues whose work deals either with the world systems concept or with the problems of measuring and delimiting the process of integration into the world economy. All periods from the 16th to the early 20 th century will be suitable for consideration.

Papers may be presented in either English or French, and CCSEE hopes that the results of the conference will eventually be published. Colleagues wishing to make a contribution should send a précis of their proposed topic(s) to Dr. E. Peter Fitzgerald, Department of History, Carleton University, Ottawa, K1S 5B6, Canada. Professor Fitzgerald will also be happy to provide all interested scholars with further information as the shape of the conference begins to take form.

As I mentioned in my last letter, CCSEE would be delighted if some members of the Centre would propose a paper or simply attend the Ottawa conference. We will be sending you more information au fur et à mesure as preparations take on a firmer form. Meanwhile, please accept our thanks for opening the pages of Itinerario to CCSEE. With best wishes,

Yours sincerely,

E. Peter Fitzgerald, Department of History,

Carleton University, Ottawa, Canada K1S 5B6. 